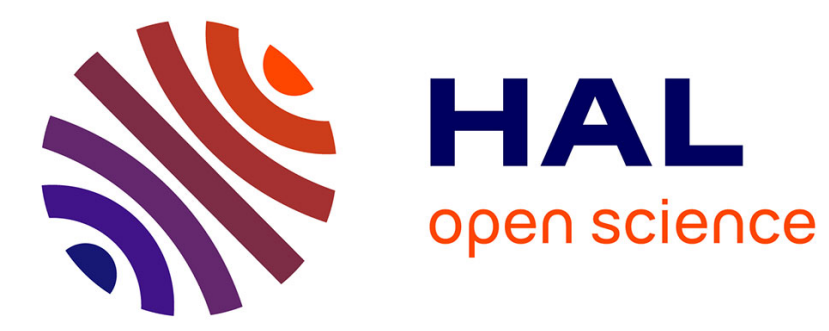

\title{
Social Shareholder Engagement: The Dynamics of Voice and Exit
}

\author{
Jennifer Goodman, Céline Louche, Katinka C. van Cranenburgh, Daniel
}

Arenas

\section{- To cite this version: \\ Jennifer Goodman, Céline Louche, Katinka C. van Cranenburgh, Daniel Arenas. Social Shareholder Engagement: The Dynamics of Voice and Exit. Journal of Business Ethics, 2014, 125 (2), pp.193-210. 10.1007/s10551-013-1890-0 . hal-01098168}

\section{HAL Id: hal-01098168 \\ https://hal-audencia.archives-ouvertes.fr/hal-01098168}

Submitted on 29 Dec 2014

HAL is a multi-disciplinary open access archive for the deposit and dissemination of scientific research documents, whether they are published or not. The documents may come from teaching and research institutions in France or abroad, or from public or private research centers.
L'archive ouverte pluridisciplinaire HAL, est destinée au dépôt et à la diffusion de documents scientifiques de niveau recherche, publiés ou non, émanant des établissements d'enseignement et de recherche français ou étrangers, des laboratoires publics ou privés. 


\section{Social Shareholder Engagement:}

\section{The Dynamics of Voice and Exit}

Jennifer Goodman, ESADE Business School, Ramon Llull University

Céline Louche, Audencia School of Management

Katinka C. van Cranenburgh, Rotterdam School of Management, Erasmus University

Daniel Arenas, ESADE Business School, Ramon Llull University 


\begin{abstract}
Investors concerned about the social and environmental impact of the companies they invest in are increasingly choosing to use voice over exit as a strategy. This paper addresses the question of how and why the voice and exit options (Hirschman 1970) are used in social shareholder engagement (SSE) by religious organisations. Using an inductive case study approach we examine seven engagements by three religious organisations considered to be at the forefront of SSE. We analyse the full engagement process rather than focusing on particular tools or on outcomes. We map the key stages of the engagement processes and the influences on the decisions made at each stage to develop a model of the dynamics of voice and exit in SSE. This study finds that religious organisations divest for political rather than economic motives using exit as a form of voice. The silent exit option is not used by religious organisations in SSE, exit is not always the consequence of unsatisfactory voice outcomes, and voice can continue after exit. We discuss the implications of these dynamics and influences on decisions for further research in engagement.
\end{abstract}

Key words: engagement process, religious organisations, responsible investment, social shareholder engagement, voice and exit 
Abbreviations:

AGM Annual General Meeting

CAAT Campaign Against Arms Trade

CIG Church Investors Group

EIAG Ethical Investment Advisory Group

ESG Environmental, social, governance

ICCR Interfaith Center on Corporate Responsibility

IRRC Investor Responsibility Research Center

JPIC Justice, Peace and Integrity of Creation

JRCT Joseph Rowntree Charitable Trust

NGO Non-governmental organisation

PETA People for the Ethical Treatment of Animals

RI Responsible Investment

SEC Securities and Exchange Commission

SSE Social Shareholder Engagement

UNPRI United Nations Principles for Responsible Investment 


\section{Figures and tables:}

Table 1 Selected Case Summaries

Table 2 Successful and Unsuccessful Engagement Processes

Figure 1 Stages of SSE by Religious Organisations 


\section{INTRODUCTION}

Shareholder engagement as a strategy for Responsible Investment (RI) is growing and social and environmental issues are increasingly included in engagement (Goldstein 2011). This "dramatic ascendancy" (Lee and Lounsbury 2011: 156) in social shareholder activism or "socially conscious shareholder advocacy" (Dhir 2012: 99), here called social shareholder engagement ${ }^{1}$ (SSE), now represents $€ 1.95$ trillion in Europe (Eurosif 2012) and a similar figure in the US at $\$ 1.54$ trillion (USSIF 2012). The prediction that SSE will become the preferred approach to RI among institutional investors (Vandekerckhove et al. 2008, Guyatt 2006, Juravle and Lewis 2008) and the driving force behind the development of RI (Gond and Piani 2013) makes it increasingly relevant to the broader corporate governance debate on active ownership. There have been calls for greater use of the voice option by asset managers and improvement in the quality of engagement by investors (Kay 2012). As investors increasingly turn from exit to voice (McLaren 2004) understanding the intricacies and dynamics of these two options by experienced engagers is valuable for both investors and firms.

Much of the corporate governance literature to date has focused on engagement by large institutional investors who seek improved financial gains by addressing the agency problem between shareholders and managers (Gillan and Starks 2007). In line with Hirschman (1970) it has been widely assumed that voice and exit are alternative options for investors, and that a failed

\footnotetext{
${ }^{1}$ The term 'social shareholder engagement' (SSE) used here attempts to reconcile the array of definitions used in the SRI and engagement literature whereby shareholders voice issues of concern to companies on particular issues (Eurosif 2006). The issues focused on in SSE are principle-based and focus on the social, environmental and ethical impacts of corporate behaviour. This also includes some governance issues related to justice such as pay inequality. SSE speaks to the socially-driven stream of engagement research identified in (Chung \& Talaulicar 2010). Governance issues with the objective of increasing financial return without regard to social, environmental and ethical impacts are not included in SSE and form part of the financially-driven stream more common in the corporate governance and finance literature.
} 
voice strategy will lead to exit (Withey and Cooper 1989). However a reading of the SSE literature demonstrates that socially-driven investors have a very different ideology to the conventional market logic (Lee and Lounsbury 2011). They engage on principle rather than on an economic basis (Chung and Talaulicar 2010, McLaren 2004) and take a broader and longer term perspective (Proffitt and Spicer 2006, Clark et al. 2008). Despite their limited financial assets, a social movement perspective shows that shareholder activists have a wide influence in terms of setting the global social issue agenda (Proffitt and Spicer 2006, Sjöström 2010). Investment on a moral basis is said to have considerable prospects for growth (Clark et al. 2008). The SSE literature has explored aspects of engagement such as the key actors (Clark and Hebb 2004, Proffitt and Spicer 2006, Barber 2007), main issues (Tkac 2006, Logsdon and Buren 2008, Rojas et al. 2009), principal targets (Judge et al. 2010, Rehbein et al. 2004) and outcomes (O'Rourke 2003, David et al. 2001, Engle 2006, Hebb et al. 2012). Research into the how SSE is undertaken has been more limited focusing on particular elements of voice engagement such as resolutions (Campbell et al. 1999, Clark et al. 2008, David et al. 2007), behind the scenes dialogue (Logsdon and Van Buren 2009), public campaigning (Guay et al. 2004, De Bakker and Den Hond 2008) and letter writing (Vandekerckhove et al. 2007) but there has been little research into the engagement process as a whole or the dynamics of the voice and exit options in this context.

This paper aims to advance research on SSE by theorising the engagement process of religious organisations and the dynamics of voice and exit options in a socially-driven shareholder engagement context. Broadly we ask how and why the voice and exit options are used in SSE. More specifically we address how engagements were undertaken by religious organisations, whether exit and voice are mutually exclusive, and when exit will be the result of a failed voice engagement. We also contrast our findings about social shareholder engagement by religious organisations to what has been described in the literature. 
This research takes a case study approach (Eisenhardt 1989) to enable us to examine the on-going engagement processes in their context (Pettigrew 1990). A qualitative process perspective is particularly suited to understanding how and why things evolve over time (Langley 1999) and has been used to develop stage models in the context of group exit (Dyck and Starke 1999). Due to the difficulty of separating influencing factors in shareholder engagement (Gillan and Starks 2007) a process approach which includes the wider context of engagement is used. This enables us to open the complex blackbox of interaction between engagers and companies (Carleton et al. 1998) and to investigate the dynamics of voice and exit options over the whole process rather than just specific elements of the process. Data is collected through interviews and desk research to analyse seven engagements on social, environmental and ethical issues by three religious organisations. We choose religious organisations as the subject of our empirical investigation because they represent an extreme example of SSE and have extensive experience in engagement (Pettigrew 1990) They perceive SSE to be one of the most influencing strategies for RI (Louche et al. 2012) but despite their pioneering role have been the subject of very little research (Louche et al. 2012, Kreander et al. 2004).

In studying the SSE processes of religious organisations, this paper makes three contributions. First we address the call to better understand engagement processes (Vandekerckhove et al. 2007, Gond and Piani 2013). Our findings identify four procedural stages of engagement: issue raising, information search, change-seeking and outcomes and detail the specific actions at each stage. Second, from the perspective of the activist we analyse the dynamics of voice and exit in SSE and extend the literature stemming from Hirschman's (1970) theory. Although they have been conceived as distinguishable options, our study reveals that they are intertwined rather than separate or sequential (Withey and Cooper 1989, Marler and Faugère 2010). This study finds that religious organisations divest for political rather than economic 
motives using exit as a form of voice. The silent exit option is not used by religious organisations in SSE, exit is not always the consequence of unsatisfactory voice outcomes, and voice can continue after exit. Furthermore this paper contributes to the wider engagement literature by identifying key factors influencing decisions for these religious organisations at each stage of the SSE process and their implications for the wider engagement debate.

The paper is organized as follows. The first part outlines the theory relevant to our research questions and sets the context for the cases. The second part presents the research design including methods and data collection. The third part concentrates on presenting and analysing the empirical data, including details of the three religious organisations and the seven engagements. Our results are discussed in part four together with their implications. Part five reflects on the limitations of our study and suggests avenues for future research. We end the paper with some conclusions.

\section{BACKGROUND LITERATURE}

This study takes an inductive approach and does not aim to test theory but rather is built around guiding concepts that already exist in the literature. Our investigation was influenced by Hirschman's (1970) theory of voice and exit and the growing body of literature on SSE which we discuss in the following subsections. This "a priori" consideration of concepts to shape our research is considered valuable by Eisenhardt in giving a "firmer empirical grounding for the emergent theory" (Eisenhardt 1989: 536).

\section{Voice and Exit}

Hirschman's (1970) classification of voice and exit strategies is referred to in the 2010 special issue of Corporate Governance: An International Review dedicated to shareholder activism (Chung and Talaulicar 2010). The framework has been used to investigate the differing mechanisms used by shareholder activists (Marler and Faugère 2010, Admati and Pfleiderer 
2009, Rojas et al. 2009, Parrino et al. 2003), and the conditions for their effectiveness (Ryan and Schneider 2002).

Exit refers to a market-based economic response to dissatisfaction with a firm's performance characterized as being straightforward, impersonal, and indirect. In investment this is often referred to as the 'Wall Street Walk' meaning the sale of shares by unsatisfied shareholders. On the contrary, voice represents a political response using communication in an attempt to rectify performance lapses (Hirschman 1970). It is "an attempt at changing the practices, policies, and outputs of the firm from which one buys or of the organization to which one belongs." (Hirschman 1970: 30). Based on dialogue, voice is far more 'messy', and implies the articulation of one's critical opinions rather than a private and anonymous market action (Hirschman 1970: 16). In a shareholder engagement context this includes activities such as filing and voting on shareholder resolutions, behind-the-scenes dialogue with management, public confrontation with management and engagement by coalitions of shareholders (Lydenberg 2007).

According to Hirschman, the decision to engage with a company rather than exiting when performance is unsatisfactory is based on two elements 1) the evaluation of the likelihood of getting the company back on track; and 2) the "judgment that it is worthwhile" to remain rather than exit (Hirschman 1970: 38). Much of the investigation into voice and exit has focused on the second of these and has been based on large institutional investors from a corporate governance perspective with a focus on the financial advantages and disadvantages of each option. Institutional investors are reluctant to use voice because of "imperfect information, limited institutional capabilities, substantial coordination costs, the misaligned incentives of money managers, a preference for liquidity, and the uncertain benefits of intervention" (Black and Coffee 1994: 2086). Thus exit is the preferred response by many institutional investors, and more common in the US than the UK (Aguilera et al. 2006, Becht et al. 2009). However this research 
does not go far enough to fully explain the exit choices in SSE. Hollenbach (1973) describes the vastly different considerations faced by religious organisations suggesting that 'exit' may be used to relieve guilt and enhance feelings of purity and righteousness by not being involved in any companies which do not meet their strict social, environmental or ethical criteria.

Voice can be an unavoidable option in the corporate governance literature, used when large stakes make it difficult or costly to divest (McLaren 2004, Black and Coffee 1994, Ryan and Schneider 2002). When institutional investors do choose to use voice it is with a view to making financial gains (Parrino et al. 2003) over and above the costs of engaging. It is dependent on traditional shareholder power: large holdings mean financial returns can outweigh the costs of engaging (Edmans and Manso 2010); some research suggests that 10-15\% of shares must be represented in order to get management attention (Black and Coffee 1994); and the financial impact on share price that the sale of large shareholdings can have (Parrino et al. 2003). Shareholders with large holdings are able to apply economic pressure and can affect management decision making through the threat of exit (Marler and Faugère 2010). This divestment threat can be considered a form of voice (Admati and Pfleiderer 2009). However, research into the salience of shareholders has demonstrated that this traditional source of power is not usually available to shareholders undertaking SSE (Gifford 2010, Lee and Lounsbury 2011) who tend to be smaller (Clark et al. 2008). Furthermore in SSE voice can be interpreted as social action and can be used for the pursuit of justice (Hollenbach 1973) or for wider social change (Proffitt and Spicer 2006, Sjöström 2010), with the financial impact being relatively inconsequential for smaller holdings typical of SSE (Clark et al. 2008). We suggest that SSE, characterised by smaller, principle-based actors, involves a greater complexity in the use of voice or exit than the corporate governance literature to date indicates. 


\section{Voice in SSE}

According to Hirschman, exit may be postponed if voice is expected to be effective and can be understood as a last resort after voice has failed. Thus exit is a consequence of an unsuccessful voice process. In this way the two options can be understood as sequential and separate although 'noisy' exits are also possible (Withey and Cooper 1989). Similarly, in the RI literature, exit (or divestment) is seen as separate and not included within the range of engagement activities (Lydenberg 2007). A voice approach to RI can take a variety of different forms, however research has tended to focus on a particular method of engagement rather than the whole process.

Many studies in the SSE literature focus on shareholder resolutions (Sjöström 2008). Since resolutions have a greater tradition in the US than in Europe, this research frequently uses databases held by US based organisations such as the Investor Responsibility Research Center (IRRC) (Campbell et al. 1999, David et al. 2007, Graves et al. 2001, Rojas et al. 2009), the Interfaith Center on Corporate Responsibility (ICCR) (Clark et al. 2008, Logsdon and Buren 2008) and others (Monks et al. 2004). The use of shareholder resolutions for social and environmental purposes dates back to the 1970s when regulation changes at the US Securities and Exchange Commission (SEC) permitted the inclusion of resolutions concerning social policy issues (Dhir 2006, Proffitt and Spicer 2006).

There are three possible outcomes for a resolution. Firstly, resolutions can be omitted by a company for not meeting the SEC requirements, for example if a resolution is identical to one submitted in the previous five years without achieving a minimum of votes or concerns matters relating to ordinary business operations (Glac 2010, Engle 2006). Secondly, engagers may withdraw their resolution before it appears on the proxy, or thirdly, resolutions may be added to the proxy statement and voted by shareholders. 
There is much disagreement on the significance of the different outcomes of resolutions particularly in SSE. According to Rojas et al. (2009) omission is most clearly seen as a form of failure. Compared to corporate governance proposals, voting levels on SSE proposals tend to be low and rarely pass (Proffitt and Spicer 2006, Sparkes and Cowton 2004, Mackenzie 1993, Campbell et al. 1999). Moreover, a high vote does not necessarily impact firm behaviour as resolutions are not binding (Engle 2006, Levit and Malenko 2011, Rojas et al. 2009). Withdrawals are also argued to represent a failure (Rojas et al. 2009) as filers attempt to avoid a low vote outcome. However, negotiated withdrawals can also be an indication that a corporation is willing to enter into dialogue (Goldstein 2011, Proffitt and Spicer 2006, Tkac 2006, Vogel 1983, Rehbein et al. 2004).

A second voice approach, dialogue between shareholders and management, extends research on resolutions enabling a better understanding of the relationship between these different tools in the broader engagement process. However, little empirical and descriptive work has been done on this (Rehbein et al. 2013). Logsdon and Van Buren (2009) suggest that behind the scenes dialogue is where the "real action typically occurs" and can result from the withdrawal of a resolution or as an alternative to filing a resolution. While there is some agreement that filing resolutions draws management attention to an issue and can lead to dialogue (Rehbein et al. 2013, Lee and Lounsbury 2011), others suggest a resolution is filed as a last resort when dialogue breaks down (Sparkes and Cowton 2004). This differing approach has also been noted among religious organisations (Louche et al. 2012).

Thirdly, shareholders can use public confrontation with companies (Guay et al. 2004, De Bakker and Den Hond 2008). An example of a public shareholder engagement campaign is the animal rights organisation People for the Ethical Treatment of Animals (PETA). They have used their rights as shareholders in numerous multinational companies since 1987 to campaign against 
animal testing for cosmetic or medical purposes (PETA 2012). As well as filing resolutions PETA also used media coverage of their campaign to try to achieve change in target companies. Still unclear in the literature is the extent of the use of media and whether it helps or hinders engagement. In governance engagement in the US, public pension funds, unions and hedge funds have used the media to raise awareness of issues and pressure managers (Gillan and Starks 2007) although behind the scenes engagement is the preferred approach of institutional investors in the UK (Aguilera et al. 2006, Black and Coffee 1994). Regulation alone is not able to sufficiently explain this difference between us and UK (Black and Coffee 1994). A social movement perspective suggests that because of their limited resources, SSE activists use the media to gain management attention (Lee and Lounsbury 2011, Proffitt and Spicer 2006). Their typically small shareholdings mean that they are not strongly penalised by any drop in share price due to campaigning and reputation attacks (Clark et al. 2008). However, Louche et al. (2012) find confrontational methods like public debate and divesting were less attractive among religious organisations than other methods of engagement.

Vandekerckhove et al. (2007) focus on one voice method, that of letter writing even though they emphasise the importance of more research into the whole engagement process. The organisational processes involved in collective engagement by institutional investors has been studied by Gond and Piani (2013) using the case of the UNPRI. Logsdon and Van Buren (2009) develop a model of the shareholder resolution process including dialogue as a response by companies. However, it does not go as far as to examine the dynamics of voice and exit options which can occur when the engagement is deemed to be unsatisfactory. Our study broadens the investigation into engagement by developing a model of the different stages of the whole process of SSE including a variety of different engagement methods, the dynamics of voice and exit and the influences on decisions at each stage. 


\section{Religious organisations}

We study seven cases of engagement undertaken by three religious organisations. In line with Pettigrew's argument for choosing case examples which represent extremes or polar types, religious organisations are a clear example of socially-driven activism. Drivers of engagement for churches and religious groups are their set of moral beliefs and religious values (O'Rourke 2003, Sparkes and Cowton 2004, Tkac 2006). That is SSE comes from a different ideological perspective than more conventional activism, based on principles rather than a market logic (Chung and Talaulicar 2010, Lee and Lounsbury 2011, McLaren 2004).

Secondly, also following Pettigrew's recommendations of choosing experienced cases, religious organisations have a long history of engaging on social, environmental and ethical issues with companies (Guay et al. 2004, Proffitt and Spicer 2006, Sparkes and Cowton 2004, Kreander et al. 2004). They are widely recognized as important and experienced actors in SSE (Louche et al. 2012, O'Rourke 2003) and have been the most active shareholders in submitting social policy and human rights proposals (Campbell et al. 1999, Dhir 2006, Monks et al. 2004, Sjöström 2008, Tkac 2006). They have been orderly and disciplined in their engagement and have taken a patient, collaborative and persistent approach (Clark et al. 2008, Proffitt and Spicer 2006, Rojas et al. 2009. The formation of umbrella organisations such as the ICCR with over 300 members representing $\$ 100$ billion in invested capital and the Church Investors' Group (CIG) with combined assets of $£ 12-13$ billion as well as the development of collaborative strategies make them highly relevant to management (Glac 2010).

Finally, religious organisations perceive SSE to be one of the most influencing RI strategies (Louche et al. 2012). Recent research shows that $90 \%$ of religious investors believe that active ownership of shares can influence corporate behaviour and over $50 \%$ indicated they were engaged as shareholders in various ways (Van Cranenburgh et al. 2010, Louche et al. 2012). 
Despite their significant and pioneering role in RI there is very limited research into engagement by religious organisations (Louche et al. 2012, Kreander et al. 2004) and there have been calls for further study in this area (Proffitt and Spicer 2006, Sjöström 2008)

\section{METHOD}

To explore the engagement processes and how voice and exit options are used in SSE, we take an inductive, case study approach. The case study method is suited to the in-depth study of a phenomenon in its real-life context where boundaries between the phenomenon and context are somewhat blurred (Yin 1994). It is also suited to research questions requiring "detailed understanding of social or organisational processes because of the rich data collected in context" (Hartley 2004: 323). Case studies are considered to be particularly valuable for enriching understanding of the processes at work in RI (Sparkes and Cowton 2004) and for complex and long-term shareholder engagement (Sjöström 2008). Using process data allows us to investigate the sequence of events over time and the wide variety of influences (Langley 1999) enabling us to gain a deeper understanding of the dynamics of voice and exit and the motives for their use. The case study method has been used in a limited number of studies. However, these are either single organisational cases (Hoffman 1996), or two comparative cases (Collier 2004, Logsdon and Van Buren 2009); a notable exception is Hebb et al. (2012) who use three cases. Eisenhardt (1989) suggests using between four and ten cases.

The multiple embedded case design allows analysis at two levels (Yin 1994): the religious organisation and the case by case engagement process. This enables us to extend our analysis beyond the seven engagement processes to develop a richer picture of the relationship between voice and exit as understood by the organisations. A descriptive and comparative approach is taken to visualize the stages of the shareholder engagement processes, identify the influences at each stage, and analyse the dynamics of voice and exit. 


\section{Case selection}

.In multiple case studies great care must be taken in defining the sampling frame, deciding the number of cases to include and dealing with the quantity of data collected, as well as ensuring an element of standardization to enable comparison (Miles and Huberman 1994).

To identify key religious organisations active in the field of engagement we conducted desk research and interviews of between forty and sixty minutes with five shareholder engagement experts familiar with the work of religious organisations in Europe, the UK and the US. These experts represent independent research institutions, Church investors, academics, and independent investment advisors all directly involved in SSE with religious organisations. These interviews helped us to identify a number of religious organisations which we classified according to the geographical location, size, religion and engagement history. The religious organisations selected for this study were chosen to represent comparable but differing characteristics in line with Eisenhardt's (1989) emphasis on theoretical sampling. The details of the organisations that participated in the study can be seen in Table 1.

Insert Table 1 about here

The main similarities between the three organisations are their Christian faith roots, their minimum of 20 years of experience in engagement with companies on social and environmental issues, and their reputation for renowned and proactive work on shareholder engagement. The primary language of the three organisations is English, and they are based in the UK and US, which are the most active national contexts (Eurosif 2010, Sparkes and Cowton 2004) and the most widely studied (Chung and Talaulicar 2010) in terms of shareholder engagement. All the organisations have an organisational separation between social, environmental and ethical decision-making and financial decision-making. 
Notable differences are the assets under management which range from $£ 150$ million to $£ 8$ billion permitting a comparison of resources, the number of companies held in the portfolios and their representation of different religious denominations. The differing legal and institutional environments for shareholder engagement in the UK and the US may affect approaches to shareholder engagement (Becht et al. 2009, Eurosif 2010, Ryan and Schneider 2002, Black and Coffee 1994). These cases therefore have been selected to offer a relatively broad spectrum of insights into engagement activities and strategies.

\section{Method and data collection}

An interview-based method was used which has been suggested as particularly informative for research in this area by Sparkes and Cowton (2004) and Sjöström (2008) and in generating insights which probe 'how' and 'why' questions (Pettigrew 1990). We also used documents such as reports, resolutions, press releases and investment policy statements and desk based research of the organisations' and related organisations' websites to enrich and validate our investigation and triangulate our findings (Yin 1994).

Although taking an inductive approach, an interview protocol was developed after reviewing the literature to ensure a link between existing theory and the inductive elements of the study (Pettigrew 1990). This was reviewed by peers familiar with the topic and refined three times to incorporate their feedback. The protocol included questions related to some of the issues raised from the literature but the questions were open to enable modifications and refinement to existing theory (Eisenhardt 1989). We held short introductory calls with the individuals who, from our research, appeared to be most closely linked to the organisation's shareholder engagement activities in order to confirm their key role in the organisation's engagement activities. Each interviewee was asked to prepare an example of a successful and an unsuccessful engagement. No further specification of the terms 'successful' and 'unsuccessful' was given 
allowing the interviewees to identify their own examples. This form of theoretical sampling (Eisenhardt 1989) encouraged the inclusion of processes with varying outcomes and facilitated the study of both voice and exit options.

Semi-structured interviews were held with the Chairman of the Ethical Investment Advisory Group (EIAG) at the Church of England, the Director of the US Justice, Peace and Integrity of Creation (JPIC) office for the Missionary Oblates of Mary Immaculate, and with the Head of Finance and the Chair of the Investment Committee at the Joseph Rowntree Charitable Trust (JRCT). These individuals were all directly involved in, and responsible for the religious organisations' engagement with the investee corporations. The interviews lasted between fifty and seventy minutes with questions designed using relevant issues from the literature to encourage detailed reflection on each engagement process. All interviews were conducted by at least two interviewers either in person or by conference call. They were recorded and transcribed.

Follow-up conversations were held with all three organisations to check some details from the main interviews and obtain missing information both from the interviewees and other staff members involved in engagement. Although each organisation's representative was asked to choose one successful and one unsuccessful example, an exception was made for the Oblates where we conducted a follow up interview with a third example. This permitted the inclusion of two different sectors within the Oblates' engagement and a consistent mining sector example for all the organisations. It further increased the dataset from the US perspective. The details of the seven engagement processes can be found in Table 2.

Insert Table 2 about here 


\title{
Data analysis
}

We have taken a highly iterative approach to our study moving from theory to data and back to theory to continuously refine our analysis. We use both within-case, and cross-case analysis (Eisenhardt 1989). Responses were discussed and coded by two researchers using NVivo to identify the key stages and the influences on decisions which we then used to further guide our empirical analysis. The emerging stages of engagement form the basis of the case analysis and were discussed regularly by all four authors.

\begin{abstract}
ANALYSIS
Before analysing how voice and exit are being used in SSE, we first present our findings with regard to the stages of SSE. This examination leads to the emergence of four main stages in engagement. Firstly, the engagement process is initiated when the issue is raised and the decision to respond is made. Second, information is sought by the religious organisations and the communication with the company begins. Thirdly, change-seeking engagement involves the range of communication methods used by the religious organisations, and finally the satisfactory or unsatisfactory outcomes lead to differing voice and exit choices. Despite dealing with different issues, locations and outcomes, we find that the stages are broadly applicable to all the engagement processes we studied. Figure 1 visualizes the methods used at each stage, the different outcomes and the influences on decisions made reported by the religious organisations. Not all the influences were present in all the cases (except for the overriding belief system).
\end{abstract}

Insert Figure 1 about here

\section{Issue raising}

The first, preliminary step in initiating the engagement process is where social, environmental or ethical issues relating to the companies in which the religious organisations 
have an investment are raised. As shown in Figure 1, issues were brought to the attention of the organisations through their organisation members or 'grassroots' networks worldwide, their network of collaborators and in one case as a direct request from the governing body of the Church of England.

While broad issues of concern were defined by core Quaker beliefs or ‘testimony', more current concerns were raised by the yearly national meeting of Quaker friends in the UK. JRCT's decisions about whether to engage on particularly contentious issues were made collectively by the Trust's investment committee (see Table 1). The decision was influenced not only by the specific issue but by pragmatic considerations such as where they thought they could make most difference with the limited time they had. An issue high on the popular agenda would encourage JRCT to add their voice and build momentum.

Despite aiming to focus on issues relevant to the main area of business of their investee companies, JRCT's engagement with Reed Elsevier is an example of the over-riding importance of their core belief system or Quaker 'testimony'. Although representing less than 1\% of Reed Elsevier's turnover the company's role in the organisation of arms fairs went in strong contradiction to the core belief in peace and conflict resolution. The issue was raised through JRCT's network of collaborators, by EIRIS, a not-for-profit responsible investment advisory service, which JRCT worked with, and by one of the JRCT Trustees who was closely linked to the NGO Campaign Against Arms Trade (CAAT).

The Vedanta case concerned human rights of the local communities in Orissa, India, over a planned bauxite mine and the expansion of an aluminium foundry on sacred land as well as the pollution from the operational foundry. The issue was raised by a number of sources from their network of collaborators including mining action groups and alerts by EIRIS. Also the 
involvement of other churches and large NGOs such as Amnesty International and Action Aid strengthened the need to act.

Decisions about engagement by the Oblates were made at the JPIC office (see Table 1) without needing authorisation from the Oblates governing body. The broad aim of JPIC is to advocate for justice for the poor around the world. They are responsive to issues and concerns raised by local communities through their missionaries who are present in around 67 countries, two thirds of these in the developing world: "We actually hear from people on the ground about some things that are going on or have gone on". This close link with the missionaries or 'grassroots' network has become fundamental to the Oblates' engagement "we don't often like to engage a company unless we do have some actual contact on the ground with local communities". A more pragmatic consideration which influenced their decisions to engage was the probability of achieving success. Thus they preferred to engage with US based companies which they claim to be much less complex, large companies with international reach, and in collaboration with others (particularly ICCR members).

The Oblates engagement with Newmont Mining was motivated by a concern for the "existing and potential opposition from local communities" in Peru, Indonesia and Ghana following reports of environmental degradation and social unrest. The issue was raised through their grassroots network through direct contact with their missionaries in the local community and demonstrates their preference for issues with global reach. The decision to engage was also influenced by the company being based in the US.

The Oblates' engagement with the financial sector, Goldman Sachs and Bank of America in particular was part of a longer-term campaign about debt cancellation. The engagement with Goldman Sachs on credit default swaps and derivatives aimed to "make the major players in the global finance system more attentive to the credit needs of... the poor". It was also timely and 
built on the awareness and concern about the financial system brought about by the 2008 financial crisis. The concern with Bank of America was a lack of ethical lending criteria to protect human rights in local communities and was raised by the grassroots network.

The Church of England has detailed ethical investment policies for a range of key issues developed by the EIAG (see Table 1) which are accessible on the EIAG website and which guide their engagement. Decisions to engage are made by the EIAG, and the Secretariat is the point of contact for concerns raised by members of the Church (see Table 1). Issues are often raised by the Church's "remarkable intelligence network around the world" which is made up of Church of England members: "through the Anglican Communion we have a very large membership all around the world which ... gives us tremendous resources".

The issue of Vedanta's "abusive attitude to communities and human rights" was raised by members of the Church locally to Vedanta's operations in India through the direct connection between the grassroots network and the EIAG. In the second case, EIAG's work with supermarkets followed a request from the Church of England General Synod to look into the relationship between supermarkets and farmers (EIAG 2007). Although the EIAG reports annually to this governing body, it is normally not involved in engagement decisions. Prompted by an investigation by the Competition Commission in the UK into the inequitable balance of power between large supermarket chains and farmers who supplied them, EIAG decided to engage at sector level with multiple stakeholders: the Government, supermarket chains and farmers. In their view this was closely related to their belief in justice, which is "very central to the New Testament”. The decision to engage was also influenced by the Church Commissioners' unique position as one of the largest owners of farmland in the UK giving EIAG "access to a level of knowledge that wouldn't have been available elsewhere or to anyone else". 


\section{Information search}

Once issues were raised and the organisations had decided to engage, shareholders began to voice their concerns with the companies and engagement moved to a second, information seeking stage. Figure 1 shows the different methods used by the religious organisations at this stage. Accurate, factual information was considered to be of key importance by all the organisations in achieving their objectives and was sought through contact with the company and other sources.

JRCT wrote initial letters to Reed Elsevier and Vedanta. The Head of Finance of JRCT explained that this is a general strategy: "we want to give the company an opportunity to explain themselves". Resources were an important influence on how to collect information. The Head of Finance was the only person involved in routine engagement and letter writing and where further investigation was needed JRCT relied on their grantees. In the case of Reed Elsevier, JRCT decided to write to the company and simultaneously approached one of their grantees to produce a report on the company's involvement in organizing arms exhibitions. The AGM was attended by two of the JRCT's trustees. JRCT explained that some engagements did not move further than the information gathering stage if the company responses were satisfactory. However, in the Reed Elsevier case the investment committee at JRCT were not satisfied with the company's responses so they moved onto the next stage of engagement. In the Vedanta case, after writing to the company and receiving an unsatisfactory response, one of JRCT's Trustees met with a representative from the local community in Orissa brought over by an NGO who informed him in detail of the situation in Orissa and prompted JRCT to continue to engage.

The Oblates JPIC staff of two were responsible for researching and writing letters to companies asking for information "our general practice is to write a letter to ask for something”. This was the process followed for the cases of Bank of America and Newmont Mining. The 
Oblates also drew on their collaborative partners such as other religious organisations under the umbrella of the ICCR, to provide "information and anecdotes". Partnerships were said to "bring diversity ... bring experience ... some accounts or ... some real life stories ... and they bring their own research capacity”. These religious partners were considered by the Director of the JPIC office to be "diligent researchers". One exception to the Oblates general practice of writing to the companies for information was the case of Goldman Sachs where the awareness raised by the current events at the time prompted them to file a resolution directly.

EIAG started all their engagement processes "by fact checking", and asking questions assuming that the company was behaving properly. This was highlighted in the Vedanta engagement: "we were very clear to ask the company for information and check our facts with the company as well so that everything ... was decided on a factual basis”.

EIAG Secretariat undertook much of its investigation internally in order to fill the information gap it identified in each case. After being dissatisfied with a video meeting with the CEO of Vedanta whilst in the UK, the Secretary of EIAG travelled independently to Orissa on a fact-finding trip where he consulted a wide range of stakeholders including a face to face meeting with the CEO, local government officials, and management, the NGO ActionAid and community members, and a number of diplomats, and development officials. The investigation did not allay the concerns EIAG had about the company's impact. In the case of the unfair practices used by supermarkets in their relations with supplier farmers, EIAG had access to a large body of information through holding shares in a number of supermarkets in the UK and through the Church's ownership of extensive areas of farmland in the UK. To take advantage of this latter source EIAG commissioned the CCLA, an SRI service provider, to produce a report "Fair Trade Begins at Home" (EIAG 2007) involving individual and group meetings with farmers over six months. From this report the injustice in the farmer-supermarket relationship became clear. With 
a strong resource base, EIAG was able to do more of its own investigation although the extensive research necessary for the production and writing of the report was undertaken by the SRI consultancy.

\section{Change-seeking}

Once an issue was raised and the facts established, voice became stronger and a range of different engagement methods were used by the religious organisations to seek change in the investee companies. The Oblates suggested: “it's like any kind of change that you're working for ... you have to use all the arrows in your quiver". These methods included attending annual shareholder meetings to ask questions, letter writing, dialogue and filing resolutions and are summarised in Figure 1. All the processes included holding meetings with companies to establish a dialogue to voice and discuss concerns.

JRCT recognised that resource limitations were an important factor in how they went about their engagement. Developing a relationship with the company through personal contact was seen as beyond their resources. However, writing letters to send directly to top managers can be done by the Head of Finance. Trustees can then judge whether the responses are satisfactory. Collaboration with other groups such as the CIG has become an important part of their engagement strategy, enabling them to share research, knowledge and human resources.

JRCT sent letters requesting information and questioning Reed Elsevier on the issue for around two years with the objective of providing the company with an opportunity to explain itself. However, they were not satisfied with the responses and requested a meeting with the company at which they wanted their NGO grantees to be present. While a noisier public campaign was building among stakeholders such as employees and customers, JRCT chose to use its position as a shareholder to get direct access to top management and attempt to also provide NGOs access to the company. The company initially resisted but finally agreed to meet JRCT 
and the NGO CAAT separately. Three of the Trustees and the Head of Finance attended the meeting where despite much discussion the company maintained their argument that their business was legal and denied any wrongdoing. In the meeting "they did promise to write to us ... but they never wrote". Further contact did not yield the requested response either. JRCT did not publicise their meeting with Reed Elsevier.

Vedanta was unresponsive to JRCT's initial letter requesting information “to actually get the communication going with them was very difficult"; "they're not listening”. Because of the geographical distance between JRCT and the Indian-based company and in order to have more impact with their limited resources, JRCT joined a UNPRI special interest group on Vedanta and added their voice to what was already a large campaign. Collaboration enabled them to have access to a telephone meeting with the company but JRCT recognized that they had "played a fairly small part”.

All of the engagements by the Oblates included the filing of a resolution. The Director of the JPIC stated: "certainly in the US tradition ... the filing of resolutions and the engagement with the company is seen as a very productive and effective way of getting to the heart of some issues". This distinction between the US and UK was also noted by EIAG: "in the US it is much more common to have specific shareholder motions which may be filed by activists and also by some investors". The Oblates saw the public nature of resolutions as an advantage: "it is public which we like, which means that it invites the participation of other shareholders and stakeholders; because it's printed in the proxy it informs them [the shareholders of the company] about an issue that other shareholders are concerned about". Furthermore, the regulations surrounding the filing of resolutions meant that legally, despite the size of the organisation the company must respond in the same way "They [the company] would have to do the same thing whether it's somebody who 
has a thousand shares or somebody who has a million shares, if there's a resolution presented, they have to respond legally".

Generally the Oblates began engagement by writing letters or meeting companies to discuss a concern. If the company responded positively to their concerns, then communication continued. However, if the response was not satisfactory then the Oblates turned to resolutions. These were filed by them or another shareholder but almost always in collaboration with other ICCR members. The Director of the Oblates JPIC office said collaboration provided "a broader base of experience and knowledge in terms of the issues", adding that "working with other partners is just in our DNA, none of us can adequately do it alone". This collaboration enabled them to overcome their resource limitations just as happened with JRCT.

The case of Goldman Sachs highlights the importance of external influences on when making decisions about how to engage. In the "midst of the financial crisis and near meltdown we were extremely eager both to focus our own thinking on this issue and also focus ... the mind of the company on the issue." Rather than sending an initial letter, which often takes weeks or months to get a reply, the Oblates chose to file a resolution thus giving the company a limited amount of time to either engage on the issue or put it on the proxy.

In contrast, EIAG stated a strong preference for behind the scenes engagement: "most of what we do is confidential and goes on with a company with a very constructive relationship". This was strongly related to the identification of their organisation as an institutional investor rather than an 'activist' and also to the national differences between the engagement process in UK and US.

EIAG generally tended to engage with investor relations, the chief executive or company chairman, and commented that approaching CSR officers can lead to a legalistic response rather than to real change: "the Chairman is often the most useful place to go as well as being the 
appropriate one”. After being unable to meet with these individuals and undertaking its own investigation, EIAG participated in discussions with other investors and in a conference call with the company. Despite these discussions, EIAG acted independently during the engagement stating that "in the main where we can we engage on our own", which enabled them to develop a clear position and move more quickly. However, they sometimes engaged with the CIG to get a larger voice on certain issues. In the case of the supermarkets, EIAG decided to engage with multiple supermarkets as well as government in order to achieve sector level change. A key influence in this decision was the highly competitive nature of the supermarket industry where regulation changes would enable a level playing field which could then lead to changes in behaviour.

\section{Outcomes}

Whilst the engagement processes were chosen as examples of successful and unsuccessful engagements, a range of different company responses was found. As shown in Figure 1, we classify the immediate outcomes of the engagement processes into 'satisfactory response', leading to company action, and 'unsatisfactory response', meaning insufficient or no change, and go on to examine the voice and exit options chosen.

Satisfactory response. Three of the engagements resulted in satisfactory action by the company in response to the request while the engagers remained shareholders. Newmont Mining produced a report about the impact of their operations on local communities following the Oblates' resolution, which achieved $95 \%$ of the votes after the company recommended that other shareholders vote for the resolution. This was unusual considering the normally low levels of voting support received by SSE resolutions (Proffitt and Spicer 2006, Sparkes and Cowton 2004, Mackenzie 1993). Despite this success, the Oblates had on-going engagement with the company to ensure that the report's findings led to change in the company. This is depicted in Figure 1 
with the higher arrow labelled 'on-going shareholder engagement'. The company's response slowed when it came to implementing the recommendations and the Oblates met with them twice over the second half of 2011. The result of this was that the company "reengaged significantly in picking up the recommendations".

The Oblates decided to withdraw their resolution with Goldman Sachs because they were satisfied with their conversation with the company. This was in line with other studies that suggest that resolution withdrawals are a positive outcome (Goldstein 2011, Proffitt and Spicer 2006, Tkac 2006, Vogel 1983). According to the Oblates, Goldman Sachs had a more robust and company-wide risk management structure in place since their engagement. Put differently, the use of voice rather than exit paid off since it led to an improvement in company performance according to the religious organisation. While the satisfactory response on this issue led to no further action, their broader on-going campaign on debt cancellation means that they continued to dialogue with Goldman Sachs on other related issues.

Finally, EIAG's engagement at sector level received the support of the competition authorities who announced the creation of a groceries market ombudsman position. Nevertheless, the Groceries Code Adjudicator Bill remains in the Parliamentary process with no adjudicator yet having been placed. In a similar way to the Oblates with Newmont Mining, EIAG remained involved with both supermarkets and the government on this issue in order to follow through with their demands. They also continued their dialogues with supermarkets in which they held shares on other sector level issues such as the clear labelling of produce. The importance of remaining engaged until change was actually implemented in the company is highlighted in all these examples.

Unsatisfactory response. The Bank of America engagement was ultimately considered to be unsatisfactory by the Oblates because the development of the requested criteria did not 
translate into substantive change at the implementation stage: "it was next to impossible ... for us to even get an example of how this criteria ... was ... applied in this situation". This engagement coincided with an important period of change for the bank, which made a number of acquisitions and sold many of their operations in the developing world to focus on the US. Despite the unsatisfactory response to their use of voice in this case, the Oblates did not exit and chose to continue their engagement by focusing on other social issues relating to the bank's larger business in the US. This is depicted in Figure 1 by the lower arrow labelled 'on-going shareholder engagement.

In contrast, three of the engagement processes included divestment by the engagers. For both EIAG and JRCT the engagement process with Vedanta resulted in the sale of their shares because they felt it was unlikely that the company would make the changes they were requesting. The Secretary of EIAG stated: "The key issue was the disconnect between the claims of the company and what I saw and heard on the ground" and the Chairman of EIAG confirmed "we were confident the company would not change its standards". One reason for EIAG and JRCT doubting that change would be made was the ownership structure of Vedanta where the Executive Chairman and his family owned a majority stake in the company. For JRCT, the divestment by other larger shareholders engaging on the same issue led them to ask, "how can we stay holding this company? They're not listening and these big organisations have put a lot of effort into trying to get them to listen and they haven't listened so we did sell our shares". Both made public announcements which explained their concerns about the companies and thus exited with voice. Although JRCT was sharing information with others on the issue, the divestment was not coordinated and they took no further action. They suggested in the interviews that such coordination could have increased the impact. They pointed out, however, that the decision to 
exit may be reached at different times by different members of a collaborative engagement and that this can add complexity to working with others.

Subsequently to divestment in 2010, EIAG engaged twice with Vedanta in 2011 and 2012, although as external stakeholders rather than shareholders. This is depicted in Figure 1 by the dashed line labelled 'external engagement'. Since then, the company has 'made appointments at a senior level to specifically look at CSR and governance and is reviewing its standards". The Chairman of EIAG regarded the engagement as "unsuccessfulish" commenting that "a process which is unsuccessful at the time may actually end up being successful as well”.

JRCT sold their shares in Reed Elsevier. JRCT felt the company did not fully address their concerns at the meeting: "they just fell back on not whether it was moral or not to make profits out of the arms trade but that basically it was legal". In a similar way Vandekerckhove et al. (2007) refer to the need to move beyond the truth value of a specific case to move forward with engagement. Finally communication fully broke down, "after about a year of waiting for this answer from them we just thought well they're just ignoring us so ... we'll sell our shares". JRCT in fact considered their engagement with Reed Elsevier to be successful. Thus the combination of voice and exit led to the desired outcome and a satisfactory response. Their public divestment from Reed Elsevier generated media coverage and "invigorated" the campaign by other stakeholders against the arms exhibition division. JRCT sold their shares in February 2007, and in July of the same year the company announced the sale of the division. JRCT chose the reinvestment option shown in Figure 1 and bought back into the company at a later date.

\section{DISCUSSION}

Having reviewed the theory of voice and exit and the different methods of engagement, we then presented seven empirical engagement processes by three religious organisations, renowned for their proactive engagement on social, environmental and ethical issues. Our 
analysis of the stages of engagement culminate in identifying the dynamics of voice and exit over time in SSE. In this section we revisit the theory underlying voice and exit and discuss this in light of our empirical findings which show the dynamics of voice and exit options. We then go on to discuss the influences on decisions made by the religious organisations in their SSE which were highlighted in our investigation.

\section{Dynamics of voice and exit}

According to Hirschman (1970), exit is an economic argument and works by creating revenue losses. Management reacts by relating lower revenue and the drop in quality. However, the shareholdings of religious organisations tend to be small, for example JRCT held less than $1 \%$ of Reed Elsevier, and therefore cannot rely on traditional shareholder power to have a financial impact on investee companies. Exit as a private and anonymous economic act was not an option. Rather, by combining divestment with public statements it was used as a political argument more in line with a voice strategy. Voice includes "various types of actions and protests, including those that are meant to mobilize public opinion" (Hirschman 1970: 30). The cases support this claim as the Chairman of EIAG referring to the Vedanta case explains: "the impact of our disinvestment ... was part of the process [it] has prompted the company to start potentially changing its behaviour". The Chair of the JRCT investment committee, referring to their divestment in Reed Elsevier, shared this view: "selling our shares was the most effective thing we've done because it ... brought this campaign into the headlines of the press and invigorated the other people like the doctors and the lawyers, and the NGOs".

EIAG's continued engagement as an external stakeholder with Vedanta despite their divestment shows that although they had 'exited' the engagement, they continued to use the voice option to maintain a dialogue with the company despite not being shareholders. By taking a fuller view of the engagement process, our empirical evidence goes further than previous studies which 
have argued that the threat of exit by large shareholders is part of voice (Admati and Pfleiderer 2009). We demonstrate that in SSE, divestment itself can be part of voice. This finding supports the work of Proffitt and Spicer (2006) that religious organisations take a longer term view of engagement and that management responses expecting a 'quick fix' are likely to prove ineffective. The persistence of religious organisations in SSE is further emphasized by the fact that even satisfactory outcomes do not necessarily lead to an end to engagement as evidence of changes is sought and further issues are picked up.

In contrast to Hirschman's assertion that exit can be a consequence of failed voice, our empirical evidence provides an example of an engager remaining a shareholder despite the fact that attempts at changing the company had failed. This leads us to suggest that exit is not a necessary consequence of failure to bring about change. Why would an investor choose to remain? Voice is more costly than exit (Hirschman 1970, Marler and Faugère 2010, Parrino et al. 2003), and religious organisations have limited resources for engagement. The cases here demonstrate how collaboration has played an important role in overcoming this cost. Connecting to other investors such as religious investor groups ICCR and CIG, and other interest groups such as the UNPRI provided a wider asset base as well as financial and knowledge resource sharing. The nature of these relationships can vary as well as their strength and scope, but they show that the dynamics of shareholder-stakeholder relations are becoming increasingly complex. Mobilizing support through forming coalitions with both religious shareholders and non-religious stakeholders has evolved over time to become a key theme in SSE (Proffitt and Spicer 2006, Van Buren 2007). Connections with these groups enabled the religious organisations to share information and access to companies, stakeholders and resources, in support of Arenas et al. (forthcoming). The Director of the Oblates JPIC said: “we've been asked by a number of people over the years who want to go to the annual general meeting of a corporation but are not 
shareholders, if we would lend them our proxies and we do". JRCT was insistent on the presence of an NGO at the meeting with Reed Elsevier. EIAG and JRCT also connected with NGOs to learn more about the issues they were engaging on.

While corporate governance engagement is concerned with weighing up the costs and benefits of engagement, religious organisations judge engagement to be worthwhile. EIAG said: "the encouragement from the members of the Church is always to do more, we've never been asked if it's worthwhile". Rather, it is the first of Hirschman's decision elements, the evaluation of the likelihood of getting the company back on track, where key voice and exit decisions will be weighed.

These findings send a clear message to companies that the engagement of religious organisations is not based on a 'rational' economic model. Rather than adhering to market-based economic behaviour, religious organisations have a commitment to engagement which goes beyond a simple voice or exit decision. They play a political and social role in their engagement with broader consequences than anonymous divestment and this should be taken into account by companies when engaging. Public exit and continuing engagement on existing and new issues, whether internally as shareholders or externally, are all variations of voice used by these religious organisations and which go beyond the typical corporate governance expectations.

\section{Influences on decisions in SSE by religious organisations}

In addition to the findings demonstrating the dynamics of voice and exit, the analysis of empirical evidence presented here also contributes to the literature on SSE by religious organisations by identifying the influences on their decisions at each stage of the process and which provide a starting point for future investigation.

As shown in Figure 1, at the initial stage of the engagement process the connections between the religious organisations and their grassroots networks were particularly important. 
This enabled the detection of social, environmental and ethical issues in communities affected by companies' operations and gave the religious organisations access to key stakeholders. EIAG stated that "there have been a number of occasions that we've had companies and we have told them things about their operations that they didn't know and they've responded positively". We suggest that this ability to detect issues and raise the voice of often unheard communities quickly and directly as shareholders is a particular asset for religious organisations.

A certain pragmatism also entered into the decisions of the religious organisations about whether to engage or not. Resources constraints affected the way the religious organisations collected information and the methods they used to engage leading them to share costs through collaboration. Alternatively by working independently EIAG could make faster decisions than if they were collaborating with other partners. Particular issues were taken up due to their timeliness in order to take advantage of current public debate and media attention to build momentum and contribute to a larger movement. At other times, distance was an obstacle in establishing communication and added unwanted complexity to engagement.

The change-seeking stage of the engagement process includes the use of a wide variety of methods of engagement which are also found in the broader engagement literature. The importance of the legal and institutional context is demonstrated by the use of resolutions by the Oblates whereby the legal obligation of a company to respond to a filing puts both small and large shareholders on a more equal footing. In order for a resolution to be filed at the SEC in the US, a shareholder must own a value of $\$ 2000$ in shares of the corresponding company for a minimum period of a year. Once this minimum is complied with, companies are obliged to respond in the same way regardless of the size of the shareholding. One of the reasons the Oblates used shareholder resolutions as a method of voicing concerns was because they informed other shareholders and enabled them to vote on particular issues. The UK based organisations 
focused more on dialogue in line with comparative research on UK and US engagement such as Aguilera et al. (2006) which suggests that in the UK institutional investors play a more consultative role whereas US SEC regulations encourage more public disclosure. EIAG confirmed "most of what we do is confidential and goes on with a company with a very constructive relationship". The effectiveness of these approaches is debated and whether behind the scenes dialogue is where the real action takes place as claimed by Logsdon and Van Buren (2009), or if more public campaigning (Guay et al. 2004, De Bakker and Den Hond 2008) can have a greater effect is yet to be resolved. The self-perception of engaging organisations as activists or institutional investors could influence the choice of approach.

Despite their limited resources and typically small shareholdings, in a number of cases the religious organisations were able to engage with senior levels of management. Meeting the 'right' people has been identified in the broader engagement literature as an important element for success (Goldstein 2011). Previous research has reported the high degree of legitimacy of SSE demands by religious organisations (Proffitt and Spicer 2006, Van Buren 2007) arguing that this is more likely to result in resolutions reaching the proxy or dialogue with a company (Logsdon and Van Buren 2009). Despite lower levels of traditional shareholder power, our empirical results suggest an advantage in being a religious organisation. EIAG claimed: "the Church of England carries a lot of moral authority in the $U K^{\prime \prime}$ which has helped to establish trust in their engagement and the Oblates see their engagement as offering a "moral compass" to companies. This legitimacy extends also to the media; the Director of Oblates JPIC said: "I don't think most companies want to be put in a position of going against a rather established well known religious institution, or their representatives, that doesn't play well in the media”. The Quaker based JRCT stated: “Although we were only a small shareholder ... we have got quite a reputation”. 
Religious organisations then may benefit, in a similar way, or perhaps more so, to NGOs, from an ability to influence which is disproportionate to the number of shares owned (Guay et al. 2004).

At the final stage, when decisions are made about whether to continue to engage or not, the likelihood of change by the company is a key consideration. Unfavorable governance structures including majority ownership in the case of Vedanta and different international governance cultures were shown to limit the use of the voice option. This coincides with Parrino et al. (2003) who find evidence which suggests that institutional owners are more likely to sell stocks rather than attempt to voice their concerns when the CEO is part of the family which founded the company. However, despite these limitations, EIAG regarded this challenge as part of a learning process "dealing with different ownership structures and different cultural structures will become much more normal". The persistent nature of religious organisations' engagement (Proffitt and Spicer 2006) and the evidence here suggest that these organisations will continue to develop and refine their engagement processes.

\section{LIMITATIONS AND FUTURE RESEARCH}

The engagement processes analysed here have been reported by the members of religious organisations directly involved in the engagement. Our objective was to understand voice and exit from the perspective of the engagers and our analysis takes these reports as its starting point. The company perspective would be a valuable source of validation for the stages of the process and the influences on the decisions made. Further research is needed to better understand how the company perceives engagement by religious organisations. Particularly challenging, however, is the frequent denial by companies that their actions are in direct response to engagement challenges and the difficulties of establishing causal links among the many factors at play (Gillan and Starks 2007). This prompts a potential line of future research into the events surrounding divestment and the prevalence and effects of pre and post-divestment engagement in SSE. 
The issue of confidentiality in dialogue (Logsdon and Van Buren 2009) also has a limiting effect on this research. EIAG comments that "I have to talk about something very public", highlighting the inability of those who engage privately to disclose information on their engagement processes. The definition of whether an engagement is public or private and the extent of media involvement in this also remains unclear. Further research into the debate between the effectiveness of 'public' versus 'private' voice methods is needed.

Our sample is small, with only three religious organisations represented. While we have chosen these organisations for their extreme position, experience, relevance to RI and comparative features the limited sample size restricts the ability to generalize the research findings. Further quantitative research on a larger sample would be useful to explore some of the points we have raised here, as would investigation into different national contexts. Although likely to be challenging, a fuller understanding of religious organisations could be developed by researching those which do not choose to engage or participate in RI. Comparative work on the processes and influences on decisions of other types of engagers such as NGOs, individual investors, SRI funds, pension funds and other institutional investors would be a logical extension to the findings shown here.

Our focus on religious organisations as social shareholder engagers rests on the assumption that religious organisations are legitimate in their concerns for improving social and environmental performance. We note however that there could be conflicting opinions about the motives and agendas of religious organisations raising doubts about their ethical objectives.

Finally, to extend the recent work of Gond and Piani (2013), research into the networks and institutions which religious organisations work within would shed further light on the nature of these relationships and the type and direction of resource flows between them. The strength 
and scope of these networks and institutions is also of great importance to companies as the dynamics between shareholders and stakeholders become more complex.

\section{CONCLUSION}

This article contributes to the growing literature on social shareholder engagement by providing in-depth insight into the engagement process itself. It models the engagement process and identifies four key stages: issue raising, information search, change-seeking, and outcomes, which religious organisations seen as highly proactive in SSE have followed. The engagements include multiple methods of engagement and detail the influences on decision at each stage. This has enabled us to consider the dynamics of voice and exit options in social shareholder engagement and is a basis for future comparative investigation on the issue.

In contrast to much of the corporate governance literature we find that religious organisations do not base their exit and voice decisions on economic considerations but political ones using voice to further their beliefs and mission in society. The silent exit option is not used by religious organisations in SSE. Voice is accepted as worthwhile and it is the likelihood of achieving change in companies which has greater influence on voice and exit decisions. We argue that Hirschman's voice and exit options are dynamic, mutually reinforcing and not necessarily sequential. Divestment does not close the door to continuing external engagement with a company nor is exit always the consequence of an unsatisfactory voice strategy. These findings extend the voice approach and the options available within it providing practical insights for both managers and other shareholders and widening the scope for future research on this topic.

The paper also sheds light on the influences on the decisions made by religious organisations in SSE. Described as pioneers in SSE, religious organisations as active and experienced engagers are influenced by a variety of pragmatic and moral considerations when 
deciding on their engagement practices to push for greater social, environmental and ethical responsibility from the companies they invest in. These insights are of vital importance for management to gain an understanding of their shareholders and stakeholders and to develop adequate responses to their concerns and persistent engagement as well as for other activists choosing a voice strategy.

\section{REFERENCES}

Admati, A. R. \& Pfleiderer, P. C. 2009. 'The 'Wall Street Walk' and Shareholder Activism: Exit as a Form of Voice.' The Review of Financial Studies, 22:7, 2445-85.

Aguilera, R. V., Williams, C. A., Conley, J. M. \& Rupp, D. E. 2006. 'Corporate Governance and Social Responsibility: a comparative analysis of the UK and the US.' Corporate Governance: An International Review, 14:3, 147-58.

Arenas, D., Sanchez, P. \& Murphy, M. forthcoming. 'Different Paths to Collaboration between Businesses and Civil Society and the Role of Third Parties.' Journal of Business Ethics.

Barber, B. M. 2007. 'Monitoring the Monitor: Evaluating CalPERS' Activism.' Journal of Investing, Winter, 66-80.

Becht, M., Franks, J., Mayer, C. \& Rossi, S. 2009. 'Returns to Shareholder Activism: Evidence from a Clinical Study of the Hermes UK Focus Fund.' The Review of Financial Studies, 22:8, 3093-129.

Black, B. S. \& Coffee, J. C. 1994. 'Hail Britannia?: Institutional Investor Behavior Under Limited Regulation.' Michigan Law Review, 92, 1997-2087.

Campbell, C. J., Gillan, S. L. \& Niden, C. M. 1999. 'Current perspectives on shareholder proposals: Lessons from the 1997 proxy season.' Financial Management, 28:1, 89-98. 
Carleton, W. T., Nelson, J. M. \& Weisbach, M. S. 1998. 'The Influence of Institutions on Corporate Governance through Private Negotiations: Evidence from TIAA-CREF.' The Journal of Finance, 53:4, 1335-62.

Chung, H. \& Talaulicar, T. 2010. 'Forms and Effects of Shareholder Activism.' Corporate Governance: An International Review, 18:4, 253-57.

Clark, G. L. \& Hebb, T. 2004. 'Pension Fund Corporate Engagement: The Fifth Stage of Capitalism.' Industrial Relations, 59:1, 142-71.

Clark, G. L., Salo, J. \& Hebb, T. 2008. 'Social and Environmental Shareholder Activism in the Public Spotlight: US Corporate Annual Meetings, Campaign Strategies, and Environmental Performance.' Environment and Planning A, 40:6, 1370-90.

Collier, J. 2004. 'Responsible Shareholding and Investor Engagement in the UK.' In G. G. Brenkert (Ed.) Corporate Integrity and Accountability: 238-52. Thousand Oaks, California: Sage Publications.

David, P., Bloom, M. \& Hillman, A. 2007. 'Investor Activism, Managerial Responsiveness, and Corporate Social Performance.' Strategic Management Journal, 28, 91-100.

David, P., Hitt, M. A. \& Gimeno, J. 2001. 'The Influence of Activism by Institutional Investors on R\&D.' Academy of Management Journal, 44:1, 144-57.

De Bakker, F. G. A. \& Den Hond, F. 2008. 'Activists' Influence Tactics and Corporate Policies.' Business Communication Quarterly, 71:1, 107-11.

Dhir, A. A. 2006. 'Realigning the Corporate Building Blocks: Shareholder Proposals as a Vehicle for Achieving Corporate Social and Human Rights Accountability.' American Business Law Journal, 43:2, 365-412. 
Dhir, A. A. 2012. 'Shareholder Engagement in the Embedded Business Corporation: Investment Activism, Human Rights, and TWAIL Discourse.' Business Ethics Quarterly, 22:1, 99118.

Dyck, B. \& Starke, F. A. 1999. 'The Formation of Breakaway Organizations: Observations and a Process Model.' Administrative Science Quarterly, 44:4, 792-822.

Edmans, A. \& Manso, G. 2010. 'Governance Through Trading and Intervention: A Theory of Multiple Blockholders.' Review of Financial Studies, 24:7, 2395-428.

EIAG 2007. 'Fairtrade begins at home: Supermarkets and the effect on British farming livelihoods.'November 2007, 1-40.

Eisenhardt, K. M. 1989. 'Building Theories from Case Study Research.' Academy of Management Review, 14:4, 532-50.

Engle, E. A. 2006. 'What You Don't Know Can Hurt You: Human Rights, Shareholder Activism and Sec Reporting Requirements.' Syracuse Law Review, 57, 63-96.

Eurosif 2006. 'European SRI Study.' http://www.eurosif.org/images/stories/pdf/eurosif_sristudy_2006_complete.pdf retreived 29th July 2012.

Eurosif 2010. 'European SRI Study.' http://www.eurosif.org/research/eurosif-sri-study/2010, retrieved 11th April 2011.

Eurosif 2012. 'European SRI Study.' http://www.eurosif.org/research/eurosif-sri-study/sri-study2012, retrieved 1st December 2012.

Gifford, E. J. M. 2010. 'Effective Shareholder Engagement: The Factors that Contribute to Shareholder Salience.' Journal of Business Ethics, 92:1 Supplement, 79-97.

Gillan, S. L. \& Starks, L. T. 2007. 'The Evolution of Shareholder Activism in the United States.' Journal of Applied Corporate Finance, 19:1, 55-73. 
Glac, K. 2010. 'The Influence of Shareholders on Corporate Social Responsibility.' Center for Ethical Business Cultures, 1-38.

Goldstein, M. 2011. 'The State of Engagement between US Corporations and Shareholders.' 1-30. IRRC Institute.

Gond, J.-P. \& Piani, V. 2013. 'Enabling Institutional Investors' Collective Action: The Role of the Principles for Responsible Investment Initiative.' Business and Society, 52:1, 64-104.

Graves, S., Rehbein, K. \& Waddock, S. 2001. 'Fad and Fashion in Shareholder Activism: The Landscape of Shareholder Resolutions, 1988-1998.' Business and Society Review, 106:4, 293-314.

Guay, T., Doh, J. \& Sinclair, G. 2004. 'Non-governmental Organizations, Shareholder Activism, and Socially Responsible Investments: Ethical, Strategic, and Governance Implications.' Journal of Business Ethics, 52, 125-39.

Guyatt, D. J. 2006. 'Identifying and Overcoming Behavioural Impediments to Long Term Responsible Investments - a Focus on UK Institutional Investors.' Department of Psychology. University of Bath, UK.

Hartley, J. 2004. 'Case Study Research.' In C. Cassell \& G. Symon (Eds.) Essential Guide To Qualitative Methods In Organizational Research: 323-33. London: SAGE.

Hebb, T., Hachigian, H. \& Allen, R. 2012. 'Measuring the Impact of Engagement in Canada.' In T. Hebb (Ed.) The Next Generation of Responsible Investing. Netherlands: Springer Publishing.

Hirschman, A. O. 1970. Exit, Voice, and Loyalty: Responses to Decline in Firms, Organizations, and States. Cambridge: Harvard University Press.

Hoffman, A. J. 1996. 'A Strategic Response to Investor Activism.' MIT Sloan Management Review, 37:2, 51-64. 
Hollenbach, D. 1973. 'Corporate investments, ethics, and evangelical poverty: a challenge to American religious orders.' Theological Studies, 34, 265-74.

Judge, W. Q., Gaur, A. \& Muller-Kahle, M. I. 2010. 'Antecedents of Shareholder Activism in Target Firms: Evidence from a Multi-Country Study.' Corporate Governance: An International Review, 18:4, 258-73.

Juravle, C. \& Lewis, A. 2008. 'Identifying impediments to SRI in Europe: a review of the practitioner and academic literature.' Business Ethics: A European Review, 17:3, 285-310.

Kay, J. 2012. 'The Kay Review of UK Equity Markets and Long-Term Decision Making.' https://http://www.gov.uk/government/publications/the-kay-review-of-uk-equity-marketsand-long-term-decision-making-final-report, retrieved 16th May 2013.

Kreander, N., McPhail, K. \& Molyneaux, D. 2004. 'God's fund managers: A critical study of stock market investment practices of the Church of England and UK Methodists.' Accounting, Auditing and Accountability Journal, 17:3, 408-41.

Langley, A. 1999. 'Strategies for Theorizing from Process Data.' Academy of Management Review, 24:4, 691-710.

Lee, M.-D. P. \& Lounsbury, M. 2011. 'Domesticating Radical Rant and Rage: An Exploration of the Consequences of Environmental Shareholder Resolutions on Corporate Environmental Performance.' Business and Society, 50:1, 155-88.

Levit, D. \& Malenko, N. 2011. 'Nonbinding Voting for Shareholder Proposals.' The Journal of Finance, 66:5, 1579-614.

Logsdon, J. \& Van Buren, H. 2009. 'Beyond the Proxy Vote: Dialogues Between Shareholder Activists and Corporations.' Journal of Business Ethics, 87, 353-65.

Logsdon, J. M. \& Buren, H. J. V. 2008. 'Justice and Large Corporations: What Do Activist Shareholders Want?' Business and Society, 47:4, 523-48. 
Louche, C., Arenas, D. \& Van Cranenburgh, K. C. 2012. 'From Preaching to Investing: Attitudes of Religious Organisations Towards Responsible Investment.' Journal of Business Ethics, $110: 3,301-20$.

Lydenberg, S. 2007. 'Universal Investors and Socially Responsible Investors: a tale of emerging affinities.' Corporate Governance: An International Review, 15:3, 467-77.

Mackenzie, C. 1993. The Shareholder Action Handbook. Newcastle, England: New Consumer Ltd.

Marler, J. H. \& Faugère, C. 2010. 'Shareholder Activism and Middle Management Equity Incentives.' Corporate Governance: An International Review, 18:4, 313-28.

McLaren, D. 2004. 'Global Stakeholders: corporate accountability and investor engagement.' Corporate Governance: An International Review, 12:2, 191-201.

Miles, M. B. \& Huberman, A. M. 1994. Qualitative Data Analysis: An Expanded Sourcebook. London: SAGE.

Monks, R., Miller, A. \& Cook, J. 2004. 'Shareholder activism on environmental issues: A study of proposals at large US corporations (2000-2003).' Natural Resources Forum, 28:4, 31730.

O'Rourke, A. 2003. 'A new politics of engagement: shareholder activism for corporate social responsibility.' Business Strategy and the Environment, 12, 227-39.

Parrino, R., Sias, R. W. \& Starks, L. T. 2003. 'Voting with their feet: institutional ownership changes around forced CEO turnover.' Journal of Financial Economics, 68:1, 3-46.

PETA 2012. 'Shareholder Campaigns.' http://www.peta.org/issues/animals-used-forexperimentation/shareholder-campaigns.aspx, retrieved 8th January 2013.

Pettigrew, A. M. 1990. 'Longitudinal Field Research on Change: Theory and Practice.' Organization Science, 1:3, 267-92. 
Proffitt, W. T. \& Spicer, A. 2006. 'Shaping the shareholder activism agenda: institutional investors and global social issues.' Strategic Organization, 4:2, 165-90.

Rehbein, K., Logsdon, J. M. \& Van Buren, H., J. 2013. 'Corporate Responses to Shareholder Activists: Considering the Dialogue Alternative.' Journal of Business Ethics, 112:1, 13754.

Rehbein, K., Waddock, S. \& Graves, S. 2004. 'Understanding Shareholder Activism: Which Corporations Are Targeted?' Business and Society, 43:3, 239-67.

Rojas, M., M'Zali, B., Turcotte, M.-F. \& Merrigan, P. 2009. 'Bringing About Changes to Corporate Social Policy through Shareholder Activism: Filers, Issues, Targets, and Success.' Business and Society Review, 114:2, 217-52.

Ryan, L. V. \& Schneider, M. 2002. 'The Antecedents of Institutional Investor Activism.' Academy of Management Review, 27:4, 554-73.

Sjöström, E. 2008. 'Shareholder activism for corporate social responsibility: what do we know?' Sustainable Development, 16, 141-54.

Sjöström, E. 2010. 'Shareholders as Norm Entrepreneurs for Corporate Social Responsibility.' Journal of Business Ethics, 94, 177-91.

Sparkes, R. \& Cowton, C. J. 2004. 'The Maturing of Socially Responsible Investment: A Review Of The Developing Link With Corporate Social Responsibility.' Journal of Business Ethics, 52:1, 45-57.

Tkac, P. 2006. 'One Proxy at a Time: Pursuing Social Change through Shareholder Proposals.' Economic Review, Federal Reserve Bank of Atlanta:Third Quarter, 1-20.

USSIF 2012. 'Report on Sustainable and Responsible Investment Trends in the United States.' http://ussif.org/resources/pubs/, retrieved 1st December 2012. 
Van Buren, H. J. 2007. 'Speaking Truth to Power: Religious Institutions as Both Dissident Organizational Stakeholders and Organizational Partners.' Business and Society Review, $112: 1,55-72$.

Van Cranenburgh, K. C., Arenas, D., Louche, C. \& Vives, J. 2010. From Faith to Faith Consistent Investing: Religious Institutions and their Investment Practices.

Vandekerckhove, W., Leys, J. \& Van Braeckel, D. 2007. 'That's not what happened and it's not my fault anyway! An exploration of managament attitudes towards SRI-shareholder engagement.' Business Ethics: A European Review, 16:4, 403-18.

Vandekerckhove, W., Leys, J. \& Van Braeckel, D. 2008. 'A Speech-Act Model for Talking to Management. Building a Framework for Evaluating Communication wthin the SRI Engagement Process.' Journal of Business Ethics, 82:1, 77-91.

Vogel, D. 1983. 'Trends in Shareholder Activism: 1970-1982.' California Management Review, $25: 3,68-87$.

Withey, M. \& Cooper, W. H. 1989. 'Predicting Exit, Voice, Loyalty, and Neglect.' Administrative Science Quarterly, 34:4, 521-39.

Yin, R. K. 1994. Case Study Research: Design and Methods. Thousand Oaks, California: SAGE. 


\section{FIGURE 1}

\section{Stages of SSE by Religious Organisations}
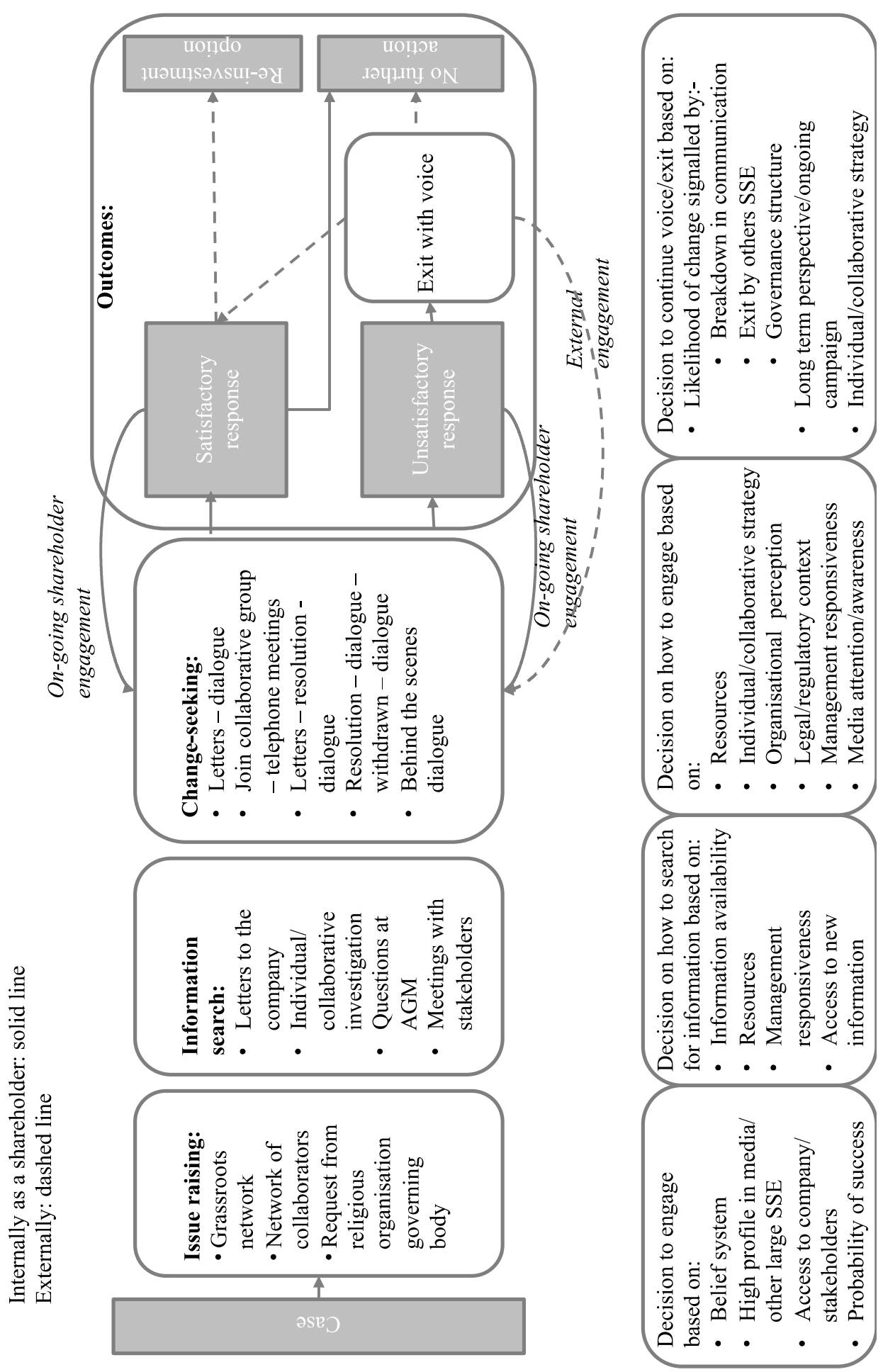


\section{TABLE 1}

\section{Selected Case Summaries}

\begin{tabular}{|c|c|c|c|}
\hline & $\begin{array}{l}\text { Joseph Rowntree } \\
\text { Charitable Trust } \\
\text { (JRCT), UK }\end{array}$ & $\begin{array}{l}\text { Missionary Oblates of } \\
\text { Mary Immaculate, US }\end{array}$ & $\begin{array}{l}\text { Church of England, } \\
\text { UK }\end{array}$ \\
\hline Organization & $\begin{array}{l}\text { Independent endowed } \\
\text { foundation }\end{array}$ & $\begin{array}{l}\text { International } \\
\text { missionary } \\
\text { congregation }\end{array}$ & $\begin{array}{l}\text { Largest Church in the } \\
\text { UK }\end{array}$ \\
\hline Denomination & Quaker & Catholic & Anglican \\
\hline Congregation & $\begin{array}{l}\text { UK based, Quaker } \\
\text { worldwide }\end{array}$ & $\begin{array}{l}\text { Italy/US based, } \\
\text { worldwide }\end{array}$ & $\begin{array}{l}\text { England based, } \\
\text { Anglican worldwide }\end{array}$ \\
\hline $\begin{array}{l}\text { Engagement } \\
\text { experience }\end{array}$ & Formally since 1970 s & $\begin{array}{l}\text { Formally since 1980s } \\
\text { (engaged since 1970s) }\end{array}$ & $\begin{array}{l}\text { Formally since } 1994 \\
\text { (engaged prior to this) }\end{array}$ \\
\hline AUM (+/-) & $£ 150-200$ million & $\begin{array}{l}\$ 450 \text { million (combined } \\
\text { Europe and US) }\end{array}$ & $£ 8$ billion \\
\hline $\begin{array}{l}\text { Ethical } \\
\text { Investment } \\
\text { policy } \\
\text { development }\end{array}$ & $\begin{array}{l}\text { Investment Committee } \\
\text { made up of six Quaker } \\
\text { Trustees and a co-optee } \\
\text { (Chief Executive of the } \\
\text { Finance Board of the } \\
\text { Methodist Church) }\end{array}$ & $\begin{array}{l}\text { Justice, Peace and } \\
\text { Integrity of Creation } \\
\text { Office US coordinates } \\
\text { the Faith Consistent } \\
\text { Investing Program }\end{array}$ & $\begin{array}{l}\text { Ethical Investment } \\
\text { Advisory Group } \\
\text { (EIAG) } 18 \text { members } \\
\text { including investors and } \\
\text { theologians, members } \\
\text { from the General Synod } \\
\text { and Archbishops } \\
\text { Council }\end{array}$ \\
\hline $\begin{array}{l}\text { Responsibility } \\
\text { for ethical } \\
\text { engagement }\end{array}$ & $\begin{array}{l}\text { Investment Committee } \\
\text { and Head of Finance }\end{array}$ & $\begin{array}{l}\text { JPIC Office US. Two } \\
\text { full time staff plus part- } \\
\text { time support }\end{array}$ & $\begin{array}{l}\text { EIAG Secretariat, two } \\
\text { members of staff }\end{array}$ \\
\hline $\begin{array}{l}\text { Investment } \\
\text { focus }\end{array}$ & $\begin{array}{l}\text { UK and European } \\
\text { listed, small-mid cap }\end{array}$ & $\begin{array}{l}\text { US listed, small-large } \\
\text { cap. }\end{array}$ & $\begin{array}{l}\text { Mostly UK listed, } \\
\text { small-large cap. }\end{array}$ \\
\hline Companies held & 100 & 600 & 2000 \\
\hline $\begin{array}{l}\text { Annual } \\
\text { engagement } \\
\text { (approximately) }\end{array}$ & 5-10 companies & $\begin{array}{l}\text { Resolutions voted, } \\
45 \text { letters, } \\
60 \text { company } \\
\text { engagements }\end{array}$ & $\begin{array}{l}\text { Resolutions voted, } \\
200 \text { letters (UK), } \\
50 \text { company } \\
\text { engagements }\end{array}$ \\
\hline
\end{tabular}


TABLE 2

Successful and Unsuccessful Engagement Processes

\begin{tabular}{|c|c|c|c|c|c|c|c|}
\hline & \multicolumn{2}{|c|}{$\begin{array}{l}\text { Joseph Rowntree } \\
\text { Charitable Trust } \\
\text { (JRCT), UK }\end{array}$} & \multicolumn{3}{|c|}{$\begin{array}{l}\text { Missionary Oblates of Mary } \\
\text { Immaculate (Oblates, JPIC), US }\end{array}$} & \multicolumn{2}{|c|}{$\begin{array}{l}\text { EIAG, Church of England, } \\
\text { UK }\end{array}$} \\
\hline & Successful & $\begin{array}{l}\text { Unsuccessf } \\
\text { ul }\end{array}$ & Successful & Successful & $\begin{array}{l}\text { Unsuccessfu } \\
\text { I }\end{array}$ & Successful & $\begin{array}{l}\text { Unsuccessf } \\
\text { ul }\end{array}$ \\
\hline Firm & $\begin{array}{l}\text { Reed } \\
\text { Elsevier } \\
\text { UK }\end{array}$ & $\begin{array}{l}\text { Vedanta } \\
\text { India \& UK }\end{array}$ & $\begin{array}{l}\text { Goldman } \\
\text { Sachs US }\end{array}$ & $\begin{array}{l}\text { Newmont } \\
\text { mining US }\end{array}$ & $\begin{array}{l}\text { Bank of } \\
\text { America } \\
\text { US }\end{array}$ & $\begin{array}{l}\text { Multiple } \\
\text { UK }\end{array}$ & $\begin{array}{l}\text { Vedanta } \\
\text { India \& } \\
\text { UK }\end{array}$ \\
\hline Sector & Publishing & Mining & Banking & Mining & Banking & Supermarkets & Mining \\
\hline $\begin{array}{l}\text { Engageme } \\
\text { nt target }\end{array}$ & Firm & Firm & Firm & Firm & Firm & Sector & Firm \\
\hline Issue & $\begin{array}{l}\text { Arms } \\
\text { fairs, } \\
\text { peace }\end{array}$ & $\begin{array}{l}\text { Environmen } \\
\text { tal impact }\end{array}$ & $\begin{array}{l}\text { Financial } \\
\text { accountabili } \\
\text { ty }\end{array}$ & $\begin{array}{l}\text { Human } \\
\text { rights }\end{array}$ & $\begin{array}{l}\text { Accountabili } \\
\text { ty and } \\
\text { human } \\
\text { rights } \\
\end{array}$ & Justice & $\begin{array}{l}\text { Human } \\
\text { rights }\end{array}$ \\
\hline $\begin{array}{l}\text { Issue } \\
\text { raised by }\end{array}$ & $\begin{array}{l}\text { CAAT } \\
\text { (NGO) } \\
\text { and EIRIS }\end{array}$ & $\begin{array}{l}\text { Churches, } \\
\text { mining } \\
\text { action } \\
\text { groups, } \\
\text { EIRIS }\end{array}$ & $\begin{array}{l}\text { Awareness } \\
\text { and } \\
\text { investigatio } \\
\text { n following } \\
\text { ENRON } \\
\text { collapse } \\
2001\end{array}$ & $\begin{array}{l}\text { Oblates } \\
\text { members in } \\
\text { communitie } \\
\text { s local to } \\
\text { operations }\end{array}$ & $\begin{array}{l}\text { Research } \\
\text { and Oblates } \\
\text { members in } \\
\text { local } \\
\text { communities }\end{array}$ & $\begin{array}{l}\text { General } \\
\text { Synod }\end{array}$ & $\begin{array}{l}\text { Church } \\
\text { members } \\
\text { and NGOs } \\
\text { local to } \\
\text { operation }\end{array}$ \\
\hline $\begin{array}{l}\text { Affected } \\
\text { stakehold } \\
\text { er }\end{array}$ & $\begin{array}{l}\text { Victims of } \\
\text { warfare }\end{array}$ & $\begin{array}{l}\text { Community } \\
\text { in Orissa }\end{array}$ & $\begin{array}{l}\text { Developing } \\
\text { countries } \\
\text { and the } \\
\text { poor }\end{array}$ & $\begin{array}{l}\text { Communiti } \\
\text { es local to } \\
\text { operations } \\
\text { in Peru, } \\
\text { Indonesia } \\
\text { and Ghana }\end{array}$ & $\begin{array}{l}\text { Developing } \\
\text { countries } \\
\text { with human } \\
\text { rights abuses }\end{array}$ & UK farmers & $\begin{array}{l}\text { Communit } \\
\text { y in Orissa }\end{array}$ \\
\hline Objective & $\begin{array}{l}\text { To stop } \\
\text { company } \\
\text { involveme } \\
\text { nt in arms } \\
\text { fairs. }\end{array}$ & $\begin{array}{l}\text { To meet } \\
\text { human } \\
\text { rights and } \\
\text { environment } \\
\text { al standards } \\
\text { at Orissa } \\
\text { plant, India }\end{array}$ & $\begin{array}{l}\text { Obtain } \\
\text { more } \\
\text { disclosure } \\
\text { on risk. } \\
\text { To make } \\
\text { financial } \\
\text { system } \\
\text { attentive to } \\
\text { credit needs } \\
\text { of poor. }\end{array}$ & $\begin{array}{l}\text { To make } \\
\text { company } \\
\text { report on } \\
\text { social } \\
\text { impact and } \\
\text { engagemen } \\
\text { t with } \\
\text { communitie } \\
\text { s }\end{array}$ & $\begin{array}{l}\text { To develop } \\
\text { and } \\
\text { implement } \\
\text { ethical } \\
\text { criteria for } \\
\text { lending }\end{array}$ & $\begin{array}{l}\text { To gain fairer } \\
\text { treatment for } \\
\text { small farmers }\end{array}$ & $\begin{array}{l}\text { To meet } \\
\text { ethical } \\
\text { social } \\
\text { standards } \\
\text { at Orissa } \\
\text { plant, India }\end{array}$ \\
\hline Duration & 3.5 years & 1.5 years & 1.5 years & $\begin{array}{l}4 \text { years } \\
\text { ongoing }\end{array}$ & $\begin{array}{l}2.5 \text { years } \\
\text { ongoing }\end{array}$ & 5 years & 9 months \\
\hline Outcome & $\begin{array}{l}\text { Divestmen } \\
\mathrm{t} \text {, sale of } \\
\text { division, } \\
\text { reinvestme } \\
\mathrm{nt}\end{array}$ & Divestment & $\begin{array}{l}\text { Dialogue, } \\
\text { resolution } \\
\text { withdrawn }\end{array}$ & $\begin{array}{l}\text { Company } \\
\text { recommend } \\
\text { ed vote for } \\
\text { resolution } \\
\text { and } \\
\text { achieved } \\
95 \%\end{array}$ & $\begin{array}{l}\text { Resolution } \\
\text { withdrawn, } \\
\text { policy } \\
\text { developed } \\
\text { but not } \\
\text { implemented } \\
\text {, remained } \\
\text { investors }\end{array}$ & $\begin{array}{l}\text { Report and } \\
\text { recommendati } \\
\text { on for } \\
\text { ombudsman } \\
\text { position }\end{array}$ & $\begin{array}{l}\text { Divestment } \\
\text {. Some } \\
\text { success in } \\
\text { subsequent } \\
\text { company } \\
\text { changes }\end{array}$ \\
\hline
\end{tabular}

